Received: 22 July 2020

Accepted: 18 September 2020

Online: 25 September 2020

Authors:

A. Kumar, A. Mazeed, D. Kumar, R. K. Verma, P. Suryavanshi $\bigotimes$, N. B. Lothe, A. Singh, N. Yadav

Division of Agronomy and Soil Science, CSIRCentral Institute of Medicinal and Aromatic

Plants, Lucknow-226015, India

$\bigotimes$ priyankaagrios@gmail.com

Emer Life Sci Res (2020) 6(2): 54-59

E-ISSN: 2395-6658

P-ISSN: 2395-664X

DOI: https://doi.org/10.31783/elsr.2020.625459
Research Article

\section{Evaluation of yield potential and nutritional quality of various cultivars of barnyard millet (Echinochloa frumentacea L.) grown under subtropical India}

\author{
Arvind Kumar, Abdul Mazeed, Dhananjay Kumar, Rajesh Kumar \\ Verma, Priyanka Suryavanshi, Nikil B. Lothe, Anjali Singh, Neelu Yadav
}

\begin{abstract}
A field experiment was carried out during kharif season 2013 at Acharya Narendra Deva University of Agriculture and Technology, Kumarganj, Faizabad to study the performance of different cultivars of sawan millet with respect to yield and nutritional quality. The experiment was laid out in a randomized complete block design with three replicates. The treatments comprised of 10 germplasms viz., NDS-1, NDS-2, NDS-3, NDS-4, NDS-5, NDS-6, NDS-7, NDS-8, NDS-9, NDS-10 and one control i.e., T-46 (Popular variety of eastern U.P). Results revealed that the germplasm NDS-9 recorded significantly higher grain yield followed by NDS-10. The highest protein content was recorded in germplasm NDS-6 followed by NDS-2. The highest tryptophan was recorded in germplasm NDS- 6 followed by NDS-3 and the highest lysine was reported in germplasm NDS- 6 followed by NDS-5 and NDS-3. The total mineral content was highest in NDS-8 followed by NDS_7 and NDS-1. The higher crude fiber was recorded in germplasm NDS-9 followed by NDS-10 and NDS-7. The lowest values of phytic acid and tannin content were also noticed in NDS-6 followed by NDS-3.
\end{abstract}

Keywords barnyard millet, germplasm, NDS-6, nutritional quality, yield

\section{Introduction}

Barnyard millet (Echinochloa spp.), also known as billion-dollar grass, madira, jhangora or sawan, is an important millet crop grown in subtropical India, Japan, and China as a substitute for rice under natural precipitation. It has a wide adaptation capacity and is grown up to an altitude of $2000 \mathrm{~m}$ above mean sea level during the summer season [1]. Among small millets, barnyard millet is the fastest growing millet and produces a crop in a short period of nine weeks from sowing to maturity [2]. The crop is known for its good yield and high nutritional value [3]. Barnyard millet is one of the underutilized, nutritious minor millet and sources of nutraceutical components. It is a multipurpose crop which is cultivated for food and fodder. It is very drought resistant and capable of withstanding waterlogging conditions. It can be grown in low fertile soil and is resistant to pest and disease.

Barnyard millet is a good source of protein that is highly digestible and an excellent source of dietary fibers [4]. The grain contains protein (15.07 $\%)$, fat (3.20-9.84\%), crude fiber (5.35-7.90\%), total mineral $(2.02 \%)$ and total carbohydrate $(68.76 \%)$, calcium $(20.31 \mathrm{mg}-32.78 \mathrm{mg}$ per $100 \mathrm{~g}$ ), phosphorus $(2.80 \mathrm{mg}$ per $100 \mathrm{~g})$, iron $(11.27 \mathrm{mg}-11.50 \mathrm{mg}$ per $100 \mathrm{~g}$ ) and total 
dietary fibre $(9 \mathrm{mg}-15 \mathrm{mg}$ per $100 \mathrm{~g}$ ). The digestability of protein is 40 per cent and anti-nutritional factors namely tannins (102.96 mg per $100 \mathrm{~g})$ and phytic acid (96.00 $\mathrm{mg}$ per $100 \mathrm{~g}$ ) are also present in this millet [5]. Niacin present in this millet lowers the cholesterol content while its insoluble fiber reduces the bile acid secretion. Its flour is gluten-free and non-allergic which prevents gallstones. Fiber from whole grain protects against breast cancer due to high antioxidant activity while serotonin calms the mood. Magnesium reduces migraine, asthma, and heart attack. Lingams, an essential phytonutrient present in sawan millet is beneficial to the human body. Under the action of intestinal friendly microflora, they are converted to mammalian lingam, which act against different types of hormone-dependent cancers like breast cancer and also helps in reducing the risk of heart disease. Sawan millet also contains a high amount of lecithin and is excellent for strengthening the nervous system. Regular consumption of millet is very beneficial for a post-menopausal woman suffering from signs of cardiovascular diseases, like high blood pressure and high cholesterol levels.

In India, the area under small millets has been steadily decreasing during the last three decades [6] and in recent years the pace of decline has been much faster [7]. Millet cultivation areas have shrunk nearly by $42 \%$ over the last 50 years between 1956 and 2006; all millet growing areas in India have moved towards other crops [8]. There are several factors responsible for this decline. Lack of suitable germplasm is one of them. Despite its significance, barnyard millet has largely been an under-researched crop compared with the main staple cereals. Millets are considered minor cereal crops of only regional importance; hence little attention has been given to collection, conservation, and evaluation of available diversity for use in crop improvement. Differences in germplasm regarding nutrient composition within the species of minor millets were reported by several investigators. Among the millets, it has been proved to be suitable for people suffering from metabolic disorders such as diabetes mellitus [9]. However, there is a need to revive the nutritional benefits of sawan millet to enhance the nutritional quality of diets of consumers. The eastern parts of Uttar Pradesh mostly suffer due to the problem of malnutrition especially in children and nursing mothers. Most of the deficiency diseases occur due to the deficiency of protein, iron, calcium, and vitamin A, which are present in sufficient amount in this millet. Keeping these facts in mind, the present experiment was carried out to find superior germplasm with regard to higher yield and nutritional quality.

\section{Methodology}

The field experiment was conducted during Kharif season, 2013 at the student instructional farm of N.D.U.A and T Kumarganj, Faizabad. The experiment was laid out in a randomized complete block design with three replicates. The soil of the experimental field was red clay loam with $\mathrm{pH} 5.9$ (1:2.5 soil to solution ratio), EC $0.47 \mathrm{dS} \mathrm{m}^{-1}$, organic C $4.0 \%$, available P $50 \mathrm{mg} \mathrm{g}^{-1}$ soil, and available $\mathrm{K} 305 \mathrm{mg} \mathrm{g}^{-1}$ soil. The treatment consists of 10 germplasms viz., NDS-1, NDS-2, NDS-3, NDS-4, NDS-5, NDS-6, NDS-7, NDS-8, NDS-9, NDS-10 and one control i.e., T-46 (Popular variety of eastern U.P). The row to row and plant to plant spacing was kept $25 \mathrm{~cm}$ and $5 \mathrm{~cm}$ apart, respectively. Recommended agronomical practices were adopted to achieve a good crop. After harvesting, the seeds of each germplasm were collected separately and used for the analysis of various physical and biochemical parameters. The seeds of each germplasm were ground into fine powder and stored in desiccator for further physical and biochemical analysis viz., protein, tryptophan, methionine, lysine, total mineral, phytic acid, and tannin content. The protein content of grain was estimated by using the Lowry's method [10], Tryptophan content by Spies and Chamber [11], Methionine content by Horn et al., [12], Lysine content by Felker et al., [13], and total mineral content by Hart and Fisher [14]. Anti-nutritional factors such as phytic acid content and tannin content were estimated by Wheeler and Ferrel [15] and Ranganna [16] method respectively. The obtained data were analyzed by using Gomez method [17].

\section{Results and Discussion}

Variation in the yield of different cultivars

Results revealed that yield ranged between $5.99 \mathrm{q} \mathrm{h}^{-1}$ to $13.44 \mathrm{q} \mathrm{h}^{-1}$ among different germplasms of sawan millet. However, a significantly higher yield was recorded in the germplasm NDS-9 (13.44 $\left.\mathrm{q} \mathrm{h}^{-1}\right)$ 
followed by NDS-10 (11.73 $\left.\mathrm{q} \mathrm{h}^{-1}\right)$ and NDS-8 (11.57 $\left.\mathrm{q} \mathrm{h}^{-1}\right)$ (Table 1). The lowest yield was recorded in the germplasm NDS-7 $\left(5.99 \mathrm{q} \mathrm{h}^{-1}\right)$. These results are in agreement with the findings of Nager and Sharma [18] who found a similar range of yield attributes in sawan millets germplasms.

\section{Variation in the biochemical characteristics of different germplasms}

\section{Protein content}

Results revealed that maximum protein content was recorded in the germplasm NDS-6 (10.46\%) followed by NDS-2 $(10.45 \%)$ and NDS-1 $(10.34 \%)$, while minimum protein content was noticed in the germplasm NDS-9 $(8.05 \%)$ (Table 1). A significant correlation was obtained regarding protein content in various sawan millet germplasm. The protein content was in the range of 8.05 to 10.46 percent. The highest and lowest protein content in the germplasm might be due to the genetic character of that germplasm. Similar results are also obtained by Veena et al., [4] who found a similar range of protein in sawan millet.

Table 1. Variation in the yield, nutritional and anti-nutritional quality of different cultivars of sawan millet

\begin{tabular}{|c|c|c|c|c|c|c|c|c|c|}
\hline $\begin{array}{l}\text { Name of } \\
\text { the } \\
\text { cultivars }\end{array}$ & $\begin{array}{c}\text { Yield } \\
\left(\mathbf{q} \mathbf{h}^{-1}\right)\end{array}$ & $\begin{array}{c}\text { Protein } \\
(\%)\end{array}$ & $\begin{array}{c}\text { Tryptophan } \\
\text { content } \\
\left(\mathrm{mg} \mathrm{g}^{-1}\right. \\
\text { protein) }\end{array}$ & $\begin{array}{c}\text { Methionine } \\
\text { content } \\
\left(\mathrm{mg} \mathrm{g}^{-1}\right. \\
\text { protein) }\end{array}$ & $\begin{array}{c}\text { Lysine } \\
\text { content } \\
\left(\mathrm{mg} \mathrm{g}^{-1}\right. \\
\text { protein) }\end{array}$ & $\begin{array}{c}\text { Total } \\
\text { mineral } \\
\text { content } \\
(\%)\end{array}$ & $\begin{array}{c}\text { Crude } \\
\text { fibre } \\
\text { content } \\
(\%)\end{array}$ & $\begin{array}{l}\text { Phytic } \\
\text { acid } \\
\text { content } \\
\left(\mathrm{mg}^{-1}\right. \\
\left.100 \mathrm{~g}^{-1}\right)\end{array}$ & $\begin{array}{c}\text { Tannin } \\
\text { content } \\
\left(\mathrm{mg}^{-1}\right. \\
\left.100 \mathrm{~g}^{-1}\right)\end{array}$ \\
\hline NDS-1 & 7.74 & 10.34 & 43.00 & 114.66 & 110.00 & 4.40 & 6.30 & 95.72 & 62.88 \\
\hline NDS-2 & 8.67 & 10.45 & 48.66 & 119.66 & 112.00 & 4.23 & 5.64 & 95.07 & 62.63 \\
\hline NDS-3 & 8.47 & 10.31 & 51.33 & 123.00 & 119.33 & 4.05 & 5.83 & 94.48 & 62.23 \\
\hline NDS-4 & 10.54 & 10.14 & 43.66 & 109.00 & 110.33 & 4.09 & 6.13 & 94.75 & 63.08 \\
\hline NDS-5 & 6.86 & 10.23 & 41.66 & 108.00 & 119.33 & 3.95 & 6.21 & 96.16 & 63.18 \\
\hline NDS-6 & 7.15 & 10.46 & 55.66 & 121.00 & 122.33 & 4.25 & 5.41 & 92.07 & 61.60 \\
\hline NDS-7 & 5.99 & 8.70 & 36.00 & 93.33 & 87.66 & 4.61 & 6.77 & 96.22 & 64.34 \\
\hline NDS-8 & 11.57 & 9.20 & 40.33 & 87.33 & 81.00 & 4.67 & 6.32 & 97.88 & 64.76 \\
\hline NDS-9 & 13.47 & 8.05 & 35.33 & 96.66 & 78.33 & 4.35 & 6.87 & 96.96 & 64.96 \\
\hline NDS-10 & 11.73 & 8.44 & 37.33 & 97.00 & 83.00 & 4.34 & 6.80 & 96.68 & 64.71 \\
\hline $\begin{array}{c}\text { Type-46 } \\
\text { (Control) }\end{array}$ & 15.35 & 9.70 & 58.00 & 108 & 99.00 & 2.06 & 6.88 & 95.10 & 61.70 \\
\hline SEm+ & 0.127 & 0.162 & 1.75 & 1.55 & 1.56 & 0.054 & 0.025 & 0.744 & 0.036 \\
\hline $\begin{array}{c}\text { CD @ } 5 \\
\%\end{array}$ & 0.350 & 0.487 & 5.16 & 4.60 & 4.62 & 0.121 & 0.069 & 2.190 & 0.011 \\
\hline
\end{tabular}

\section{Tryptophan content}

Tryptophan plays an important role in the biosynthesis of nicotinamide (B6) that is involved in various metabolic processes. The tryptophan content recorded in different germplasm was in the range of 35.33 to $55.66 \mathrm{mg} \mathrm{g}^{-1}$ protein. Significantly higher tryptophan was recorded in the germplasm NDS-6 (55.66 mg g protein) and NDS-3 (51.33 $\mathrm{mg} \mathrm{g}^{-1}$ protein). Minimum tryptophan was noticed in the germplasm NDS-9 (35.33 $\mathrm{mg} \mathrm{g}^{-1}$ protein) and NDS-3 (51.33 $\mathrm{mg} \mathrm{g}^{-1}$ protein) (Table 1). These results are in accordance with the findings of Chen et al., [19] and Gopalan et al., [20].

\section{Methionine content ( $m g \mathrm{~g}^{-1}$ Protein)}

Methionine is a sulfur-containing amino acids that is involved in biochemical reactions especially the transmethylation reaction of the biological system. From the obtained results, it was found that methionine content was recorded in the range of 87.33 to $123.00 \mathrm{mg} \mathrm{g}^{-1}$ protein. Maximum methionine content was recorded in the germplasm of NDS-3 (123 mg g ${ }^{-1}$ protein) followed by NDS-6 (119.66 $\mathrm{mg} \mathrm{g}^{-1}$ protein) and NDS-2 (107.5 $\mathrm{mg} \mathrm{g}^{-1}$ protein) (Table 1) while minimum methionine content was noticed in the germplasm NDS-8 (87.33 $\mathrm{mg} \mathrm{g}^{-1}$ protein) (Table 1).

\section{Lysine content}

Lysine is one of the important amino acids involved in various biochemical reactions. The variation of lysine content in different germplasm was between 78.33 to $122.33 \mathrm{mg} \mathrm{g}^{-1}$ protein. Maximum lysine 
content was noticed in the germplasm NDS-9 $\left(78.33 \mathrm{mg} \mathrm{g}^{-1}\right.$ protein) (Table 1). The variation in the lysine content in the germplasm might be due to the genetic character of that germplasm. These results are in agreement with the findings of Chen et al. [19] where it was reported that among the millets, barnyard millet has lysine amino acid content of $2.9 \mathrm{mg}$ per $100 \mathrm{~g}$ of protein.

\section{Total mineral content}

The total mineral content recorded in sawan millet was in the range of 3.95 to 4.67 percent. The maximum total mineral content was recorded in the NDS-8 (4.67\%) germplasm, while the minimum total mineral content was noticed in the NDS-5 germplasm $(3.95 \%)$ (Table 1). The highest and lowest total mineral content in the germplasm might be due to the genetic character of that germplasm [4]. These results are in agreement with the findings of Roopashree [21] and Hademani and Mallesi [22].

\section{Crude fiber content}

Results revealed that variation in the crude fiber content of the germplasm was in the range of 5.41 to 6.87 percent. The maximum crude fiber content was recorded in the germplasm NDS-9 (6.87 \%), while the minimum crude fiber content was noticed in the germplasm NDS-6 (5.4\%) (Table 1). A significant correlation was noticed in the crude fiber content of various sawan millet germplasm. The highest and lowest crude fiber content in the germplasm might be due to the genetic character of that germplasm [5]. The high dietary fiber including soluble and insoluble fractions was also studied by Roopashree et al. [21] which enhanced the nutritional quality of sawan millet. A similar range of crude fiber content was also reported by Veena et al., [4] who found that dietary fiber content is fairly high with insoluble and soluble fractions.

\section{Anti-nutritional factors \\ Phytic acid content}

The phytic acid content was recorded in the range of 92.07 to $98.68 \mathrm{mg}$ per $100 \mathrm{~g}$. Maximum phytic acid content was recorded in the germplasm NDS-10 (98.68 mg per 100g), while minimum phytic acid content was noticed in the germplasm NDS-3 (92.27 mg per 100g) (Table 1). Phytic acid is an important parameter of minor millet seeds that serve as a store of phosphate for seeding, but its phosphate group carries a negative charge which binds with calcium, iron, and zinc ions. This reduces the availability of these minerals to human beings and can result in deficiency symptoms even when the diet appears adequate. These results are in agreement with the findings of Ugare, [9] who found 96.0\% phytic acid content in barnyard millet.

\section{Tannin content}

The tannin content varied among different germplasm in the range of 61.60 to $64.96 \mathrm{mg}$ per $100 \mathrm{~g}$. The germplasm NDS-9 recorded significantly higher tannin content $(64.96 \mathrm{mg}$ per $100 \mathrm{~g})$ which is not good for consumption. However, significantly lower tannin content was noticed in the germplasm NDS-6 (61.60 mg per $100 \mathrm{~g}$ ) (Table 1). Tannin is polyphenolic materials which can precipitate protein from the solution. They contain O-dihydroxy phenol groups which allow them to form hydrogen bonds and hydrophobic bonds with protein. Tannins are hydrolysable which consists of simple phenolics such as gallic acid condensed with a glucose molecule. The condensed tannins are proanthocyanidins which are complex and ready hydrolyzed as given by Chesworth et al., [23]. The obtained results are in agreement with the findings of Dey and Harborne [24] and Ugare, [9] who found the tannin content in barnyard millet.

\section{Conclusion}

From the obtained results, it can be concluded that the germplasm NDS-9 recorded significantly higher grain yield followed by NDS-10. The highest protein content was recorded in germplasm NDS-6 followed by NDS-2. The highest tryptophan was recorded in germplasm NDS-6 followed by NDS-3 and the highest lysine was reported in germplasm NDS-6 followed by NDS-5 and NDS-3. The total mineral content 
was found to be highest in NDS-8 followed by NDS-7 and NDS-1. The higher crude fiber was recorded in germplasm NDS-9 followed by NDS-10 and NDS-7. Minimum phytic acid was noticed in NDS-6, while lowest tannin content was observed in NDS-6 followed by NDS-3. Based on the overall observations, the germplasm NDS-6, NDS-8, NDS-9, and NDS-3 were rated superior. The screening of superior genotypes of Sawan millet identified in the present study could be useful in crop improvement programs, climate-resilient agriculture, and improving food security in areas with limited resources.

\section{References}

[1] A. Gupta, V. Mahajan, M. Kumar and H. S. Gupta (2009). Biodiversity in the barnyard millet (Echinochloa frumentacea Link, Poaceae) germplasm in India. Genet. Resour. Crop Evol., 56: 883889.

[2] A. K. Trivedi, L. Arya, S. K. Verma, R. K. Tyagi and A. Hemantaranjan (2017). Evaluation of barnyard millet diversity in central Himalayan region for environmental stress tolerance. J. Agric. Sci., 155: 14971507.

[3] D. Prabha, Y. K. Negi, and V. K. Khanna (2010). Morphological and isozyme diversity in the accessions of two cultivated species of barnyard millet. Nature and Sci., 8: 71-76.

[4] Veena Bharati, B., V. Chimmad, R. K. Naik, and G. Shanthakumar (2010). Physico-Chemical and Nutritional Studies in Barnyard Millet. Karnataka J. Agril. Sci., 18: 101-105.

[5] L. R. Kulkarni, R. K. Naik and P. A. Katarki (1992). Chemical composition of minor millets. Karnataka J Agricl. Sci., 5: 255-258.

[6] F.A.O., Faostat (2014). Available online: http://www. fao. org/faostat/en/\# data. QC (accessed on January 2018).

[7] V. Joshi (2013). Assessment of genetic variability and identification of genotypes for different traits in barnyard millet (Echinochloa spp.). Int. J. Agri.Food Sci., 4: 65-67.

[8] P. V. Sateesh (2010). Millets: future of food and farming. Hyderabad: Millet Network of India Deccan Development Society FIAN, pp2-9.

[9] R. Ugare (2008). Health benefits, storage quality and value addition of barnayrd millet (Echinochloa frumentacaea Link.). M. Sc. Thesis, Department of Food Science and Nutrition, College of Rural Home Science, University of Agricultural Sciences, Dharwad.

[10] O. H. Lowry, N. J. Rosenberg, A. L. Farr and R. J. Randall (1951). Estimation of protein by Lowry's method. J. Biol. Chem., 193: 265-275.

[11] J. R. Spies and D. C. Chambers (1949). Chemical determination of tryptophan in proteins. Anal. Chem., 21: $1249-1266$.

[12] M. J. Horn, D. B. Jones and A. E. Blum (1946). Colorimetric determination of methionine in proteins and foods. J. biol. Chem., 166: 313-320.

[13] P. Felker, C. K. Labanauskas and G. Waines (1978). A colorimetric screening assay for lysine in wheat using Trinitrobenzesulfonic Acid 1. Crop Sci., 18: 489-490.

[14] F. L. Hart and H. J. Fisher (2012). Modern food analysis. Springer Science and Business Media.

[15] E. L. Wheeler and R. E. Ferrel (1971). A method for phytic acid determination in wheat and wheat fractions. Cereal Chem., 48: 312-320.

[16] S. Ranganna (1986). Handbook of analysis and quality control for fruit and vegetable products. Tata McGraw-Hill Education.

[17] D. Gomez (1984). Method for preparing a fibrous sheet. U.S. Patent 4,487,657.

[18] D. K. Nager and G. L. Sharma (2005). Effect of nitrogen and phosphorus on growth, yield attributes and yield of barnyard millet (Echinochloa frumentacaea L.) varieties. Haryana J. Agronomy. 21:

[19] W.-J. L. Chen, J. W. Anderson and D. Jennings (1984). Propionate may mediate the hypocholesterolemic effects of certain soluble plant fibers in cholesterol-fed rats. Proc. Soc. Exp. Biol. Med., 175: 215-218. 
[20] C. Gopalan, B. V. R. Sastri, S. C. Balasubramanian, B. S. N. Rao, Y. G. Deosthale and K. C. Pant (2002). Nutritive value of Indian foods, revised ed. Hyderabad: National Institute of Nutrition, Indian Council of Medical Research.

[21] J. P. Ruiz-Santaella, F. Bastida, A. R. Franco and R. De Prado (2008). Morphological and molecular characterization of different Echinochloa spp. and Oryza sativa population. J. Agric. Food Chem. 54: 1166-1172.

[22] N. A. Hadimani and N. G. Malleshi (1993). Studies on milling, physico-chemical properties, nutrient composition and dietary fibre content of millets. J. Food Sci. Technol. (India), 30: 17-20.

[23] J. M. Chesworth, T. Stuchbury and J. R. Scaife (2012). An introduction to agricultural biochemistry. Springer Science and Business Media.

[24] P. M. Dey and J. B. Harborne (1997). Plant biochemistry. Elsevier. 